Journal of Animal and Feed Sciences 1, 1992, $165-170$

\title{
The effect of pectinolytic yeasts on rumen microflora
}

\author{
V. Kmet'1, Zuzanna Jonecová and Maria Stachová \\ Institute of Animal Physiology, Slovak Academy of Sciences ${ }^{1}$ and Institute of Experimental Veterinary \\ Medicine, \\ 04001 Košice, Czecho-Slovakia
}

(Received 7 February 1992; accepted 1 June 1992)

\begin{abstract}
The effect of pectinolytic yeast culture Kluyveromyces marxianus CCY 51-1-1 on growth (total anaerobes, cellulolytic, amylolytic and pectinolytic bacteria) and enzyme activities (cellulase, amylase, pectinase and urease) of the rumen microflora were investigated. Significant increase of cellulase and $\alpha$-amylase activities were found in experiment with 24 hours incubation in vitro in rumen liquid from calves or rams. Enhanced cellulase, $\alpha-$ amylase, pectinase activities and a decrease in urease activity were observed after three weeks of addition of yeast cultures to the diet of sheep. No significant effect on the rumen bacterial counts was observed in either type of the experiments. The concentration of yeast supplement was stable for eight hours when cultivated in vitro in rumen liquor.
\end{abstract}

KEY WORDS: pectinolytic yeast, rumen microflora, enzyme activity

\section{INTRODUCTION}

Previous studies have suggested that yeast culture supplements can have a significant influence on the performance of ruminants. Benefitial effects of these supplements have been associated with their abilities to alter rumen function (Dawson et al., 1990). Many biotechnological companies (Alltech from USA - Yea Sacc; United Molasses from England - Diamond V; Lallemand from Canada - Biosaf) use preparations of yeast culture Saccharomyces cerevisiae for these purposes. The aim of our experiments was to investigate the effect of another yeast species, the pectinolytic yeast Kluyveromyces marxianus, on the rumen microflora activity.

MATERIAL AND METHODS

Yeast supplement: In both types of experiments was used strain Kluyveromyces marxianus CCY 51-1-1, obtained from Czechoslovak collection of yeasts in 
Bratislava. Yeasts were cultivated in malt extract medium and used in liquid form.

Rumen fermentation cultures: Rumen liquor from three milk fed calves (fed by 10 1 milk replacer, $300 \mathrm{~g}$ concentrate mixture and hay to appetite) and two rams (fed by the same high fiber diet as sheep in in vivo trial) respectively, were withdrawn by stomach tube and mixed 1:2 (one part of rumen liquor and two parts of medium) with medium containing: $\mathrm{NaHCO}_{3} 0.98 \%, \mathrm{Na}_{2} \mathrm{HPO}_{4} \cdot 12 \mathrm{H}_{2} \mathrm{O} 0.7 \%$, $\mathrm{KCl} 0.058 \%, \mathrm{CaCl}_{2} 0.004 \%, \mathrm{MgSO}_{4} \cdot 7 \mathrm{H}_{2} 00.012 \%$, yeast extract $0.05 \%$, vitamine solution (B - complex Spofa and Kanavit Biotika, CSFR) $0.1 \%$, mineral solution (Caldwell, Bryant 1966) $0.1 \%$, urea $0.05 \%$, glucose, fructose and sucrose $0.5 \%, \mathrm{pH} 6.5$ and replaced into $100 \mathrm{ml}$ flasks with rubber stoppers. All manipulations with rumen contents were made under carbon dioxide. Into six flasks $1 \mathrm{ml}$ of yeast culture $\left(10^{5}\right.$ colony forming units - c.f.u. $)$ were added. All flasks (control group of six flasks was without yeasts) were cultivated 24 hours at $38^{\circ} \mathrm{C}$.

In vivo feeding trial: Eight sheep $(35-40 \mathrm{~kg})$ were fed $(2.5 \mathrm{~kg})$ twice a day by high fiber diet containing hay $(85 \%)$, ground barley $(15 \%)$ and mineral supplement. Four of them received yeast culture supplement $\left(10^{9}\right.$ c.f.u. - total dose in $\left.5 \mathrm{ml}\right)$ twice a day (experimental group) and four sheep were the control group (without yeasts or medium). The samples were collected two times during the third week of experiment, $3 \mathrm{~h}$ after feeding.

Microbiological techniques: Total anaerobes were determined on the RGCA medium (Bryant, Burkey 1953); cellulolytic, amylolytic, pectinolytic and xylanolytic bacteria were counted in the RGCA medium modified to contain $0.4 \% \mathrm{P}$ - cellulose, $1 \%$ maize starch, $1 \%$ pectin and $0.2 \%$ Remazol brilliant blue - xylan (Farkas et al., 1985) respectively, as a sole source of carbon. All media were incubated in $38^{\circ} \mathrm{C}$. Live yeasts were enumerated on malt extract agar supplemented with chloramphenicol $\left(100 \mu \mathrm{g} \cdot \mathrm{ml}^{-1}\right)$ and penicilin (400 IU. $\mathrm{m}^{-1}$ ).

Enzyme activities: Endoglucanase activity was measured by method of releasing reducing sugars (Somogyi, 1952) from $\mathrm{P}$ - cellulose. Results are expressed in $\mu \mathrm{g}$ glucose $\cdot \mathrm{ml}^{-1} \cdot \mathrm{h}^{-1}$. Activity of pectinolytic enzymes were determined by viscosimetric measurement (Wojciechowicz, 1971). Results are expressed as per cent decrease of the relative viscosity of the $0.5 \%$ pectin solution in samples of rumen fluid before incubation and after $48 \mathrm{~h}$ incubation at $38^{\circ} \mathrm{C} . \alpha$-amylase activity was estimated by blue starch colour Spofa test. Results are expressed in nkat $\cdot \mathrm{ml}^{-1}$. The urease activity was measured with Cook (1976) method. 


\section{RESULTS}

The survival of live yeast supplement $\left(10^{5}\right.$ yeasts $)$ in vitro in rumen calves or rams fermentation cultures was investigated in first series of experiments (Table 1). The concentration of yeasts was stable for up to 6 or 8 hours of cultivation in calf or ram rumen fluid, respectively, while after $24 \mathrm{~h}$ cultivation the yeast counts decreased in comparison with that determined immediately after inoculation. The concentrations of live yeast in samples of rumen fluid before inoculation were lower than 1.00 c.f.u. per $\mathrm{ml}$.

TABLE 1

Concentration of live yeast Kluyveromyces marxianus during $24 \mathrm{~h}$ cultivation in vitro in the rumen fluid of calves and rams (means \pm SEM of 6 observations).

\begin{tabular}{lll}
\hline Time (hour) & \multicolumn{2}{l}{ Concentration of live yeast in $1 \mathrm{ml}(\log 10 \pm \mathrm{SEM})$} \\
& Calves & Rams \\
\hline before inoculation & $\langle 1.0$ & $\langle 1.0$ \\
0 & $5.34 \pm 0.04$ & $5.45 \pm 0.02$ \\
2 & $4.43 \pm 0.10$ & $5.05 \pm 0.02$ \\
4 & $5.18 \pm 0.06$ & $5.57 \pm 0.04$ \\
6 & $5.26 \pm 0.02$ & $5.56 \pm 0.03$ \\
8 & $\mathrm{ND}$ & $5.42 \pm 0.12$ \\
24 & $2.62 \pm 0.22^{a}$ & $4.87 \pm 0.02^{b}$ \\
\hline
\end{tabular}

ND - not determined, ${ }^{a, b}-\mathrm{P}<0.01$

The effect of the live yeast culture supplement on bacterial counts and enzymes activities at $24 \mathrm{~h}$ incubation in vitro in rumen liquor from rams are shown in Table 2. No significant effect of yeast supplementation on bacterial counts of total anaerobes, that is, pectinolytic or cellulolytic bacteria was observed. However, there was a significant increase of the cellulase $(P<0.01)$ and $\alpha$ - amylase $(\mathrm{P}<0.001)$ activity in experimental group.

Similar results were obtained from an analogous experiment with 24 $\mathrm{h}$ incubation in vitro rumen liquor from milk fed calves (Table 3 ).

On the basis of those preliminary results the next series of in vivo feeding trials were carried out. Total anaerobes, pectinolytic, cellulolytic, amylolytic and xylanolytic bacteria concentrations and cellulase, $\alpha-$ amylase, pectinase and urease activities are shown in the Table 4. Addition of yeast culture to the diet resulted in significant increase of cellulase, amylase and pectinase activities $(\mathrm{P}<0.05)$ and decrease of urease activity $(\mathrm{P}<0.01)$. 
TABLE 2

The effect of pectinolytic yeast Kluyveromyces marxianus on the $24 \mathrm{~h}$ fermentation in vitro in rumen liquid from rams fed a hay-concentrate diet

Group

\begin{tabular}{lcc} 
Indices & experimental & control \\
\hline Bacteria species & Bacterial count $(\log 10 \pm \mathrm{SEM})$ \\
Pectinolytic bacteria & $8.12 \pm 0.12$ & $8.23 \pm 0.23$ \\
Cellulolytic bacteria & $6.89 \pm 0.05$ & $6.88 \pm 0.06$ \\
Total anaerobes & $8.79 \pm 0.10$ & $8.73 \pm 0.14$ \\
\hline Enzymes & \multicolumn{2}{c}{ Enzyme activity } \\
Cellulase $\left(\mu \mathrm{g} \cdot \mathrm{ml}^{-1} \cdot \mathrm{h}^{-1}\right)$ & $5.93 \pm 0.01^{a}$ & $3.48 \pm 0.01^{b}$ \\
Amylase $\left(\mathrm{nkat} \cdot \mathrm{ml}^{-1} \cdot \mathrm{h}^{-1}\right)$ & $4.98 \pm 0.08^{A}$ & $3.75 \pm 0.08^{B}$ \\
Urease $\left(\mu \mathrm{mol} \cdot \mathrm{ml}^{-1}\right)$ & $13.73 \pm 1.62$ & $15.41 \pm 0.56$ \\
Pectinase $(\%)$ & $58 \pm 4$ & $65 \pm 4$ \\
\hline Means $\pm \mathrm{SEM} \mathrm{of} 6$ observations, ${ }^{a, b}-\mathrm{P}<0.01,{ }^{A, B}-\mathrm{P}<0.001$
\end{tabular}

TABLE 3

The effect of pectinolytic yeast Kluyveromyces marxianus on the $24 \mathrm{~h}$ fermentation in vitro in rumen liquid from calves fed on a hay-concentrate and milk replace diet.

\begin{tabular}{lcc}
\hline & \multicolumn{2}{c}{ Group } \\
Indices & experimental & control \\
\hline Bacteria species & Bacterial count $(\log 10 \pm \mathrm{SEM})$ \\
Pectinolytic bacteria & $8.13 \pm 0.09$ & $8.02 \pm 0.02$ \\
Cellulolytic bacteria & $7.20 \pm 0.32$ & $7.12 \pm 0.35$ \\
Total anaerobes & $8.51 \pm 0.25$ & $8.31 \pm 0.31$ \\
\hline Enzymes & \multicolumn{2}{c}{ Enzyme activity } \\
Cellulase $\left(\mu \mathrm{g} \cdot \mathrm{ml}^{-1} \cdot \mathrm{h}^{-1}\right)$ & $5.52 \pm 0.95^{a}$ & $2.16 \pm 0.52^{b}$ \\
Amylase $\left(\mathrm{nkal} \cdot \mathrm{ml}^{-1} \cdot \mathrm{h}^{-1}\right)$ & $10.08 \pm 0.30^{A}$ & $6.76 \pm 0.22^{B}$ \\
Urcasc $\left(\mu \mathrm{mol} \cdot \mathrm{ml}^{-1}\right)$ & $8.06 \pm 0.98$ & $10.16 \pm 0.44$ \\
\hline Means $\pm \mathrm{SEM} \mathrm{of} 6$ observations, $^{a, b}-\mathrm{P}<0.05,{ }^{A, B}-\mathrm{P}<0.01$
\end{tabular}

\section{DISCUSSION}

The ability of yeast culture supplements based on Saccharomyces cerevisiae to alter ruminal microbial population has been reported recently. Addition of yeast to diets of non lactating cows tended to increase the number of total anaerobic bacteria and increased number of cellulolytic bacteria (Wiedmeier et 
TABLE 4

The effect of pectinolytic yeast Kluyveromyces marxianus after 21 days on the rumen fermentation of sheep given a hay-concentrate diet.

\begin{tabular}{lcc}
\hline & \multicolumn{2}{c}{ Group } \\
Indices & experimental & control \\
\hline Bacteria specics & Bacterial count $(\log 10 \pm \mathrm{SEM})$ \\
Pectinolytic bacteria & $7.74 \pm 0.19$ & $7.69 \pm 0.14$ \\
Ccllulolytic bacteria & $6.62 \pm 0.16$ & $6.87 \pm 0.17$ \\
Amylolytic bacteria & $7.40 \pm 0.18$ & $7.29 \pm 0.18$ \\
Xylanolytic bacteria & $6.72 \pm 0.12$ & $6.50 \pm 0.09$ \\
Total anaerobes & $8.25 \pm 0.13$ & $7.85 \pm 0.19$ \\
\hline Enzymes & \multicolumn{2}{c}{ Enzyme activity } \\
Cellulase $\left(\mu \mathrm{g} \cdot \mathrm{ml}^{-1} \cdot \mathrm{h}^{-1}\right)$ & $8.64 \pm 0.22^{a}$ & $7.61 \pm 0.24^{b}$ \\
Amylase $\left(\mathrm{nkat} \cdot \mathrm{ml}^{-1} \cdot \mathrm{h}^{-1}\right)$ & $4.95 \pm 0.15^{a}$ & $4.39 \pm 0.17^{b}$ \\
Urease $\left(\mu \mathrm{mol} \cdot \mathrm{ml}^{-1}\right)$ & $49.41 \pm 3.6^{A}$ & $72.2 \pm 6.4^{B}$ \\
Pcctinase $(\%)$ & $65 \pm 6$ & $49 \pm 3$ \\
\hline Means $\pm \mathrm{SEM} \mathrm{of} 6$ observations, $^{a, b}-\mathrm{P}<0.05,{ }^{A, B}-\mathrm{P}<0.01$
\end{tabular}

al., 1987). The similar results have been described by Harrison et al. (1988) with cows which were fed a diet of $40 \%$ corn silage and $60 \%$ concentrate. The concentration of anaerobic bacteria tended to be higher while cellulolytic bacteria concentration was significantly greater in cows fed $\mathrm{S}$. cerevisiae than in cows receiving control diet. However, the increase in the number of cellulose degraders in the rumen did not effect the level of fibre digestion.

The results reported in this paper did not confirm with the mode of action of S. cerevisiae (Wallace, 1992), for there were no increases in the counts of viable rumen bacteria in the rumen liquor of any experimental groups (in vitro or in vivo). There were however significantly higher enzyme activities (with the exception of urease which was reduced), in all the experimental groups in both types of our experiments (in vitro and in vivo).

The concentrations of live yeast cells in the rumen have been reported to be low, but they were dependent on the type of diet consumed by the animal (Lund, 1974). Similary, the strain of S. cerevisiae used has also been shown to be important (Newbold and Wallace, 1992). The pectinolytic yeast K. marxianus used by ourselves did not growth extensively in the rumen, but after eight hours cultivation in the rumen fluid its concentration was maintained at approximately the same level as immediately after supplementation. Dawson et al. (1990) also have reported similar behaviour of S. cerevisiae yeast in the rumen of steers and in continuous cultures. Live yeast cultures present in the rumen may influence fermentation processes their own metabolic activities. 


\section{CONCLUSIONS}

Supplementation of a pectinolytic yeast culture to diets of calves and sheep changes the enzyme activity (cellulase and $\alpha$-amylase or urease and pectinase) of rumen microflora. No effect was found on rumen bacterial counts. These results suggest that live yeast culture supplement stimulate rumen microbial activities.

\section{REFERENCES}

Bryant M.P., Burkey L.A., 1953. Cultural methods and some characteristics of some of the more numerous groups of bacteria in the bovine rumen. J. Dairy Sci. 41, 1747-1750

Caldwell D.R., Bryant M.P., 1966. Medium without rumen fluid for nonselective enumeration and isolation of rumen bacteria. Appl. Microbiol. 14, 794-801

Cook A.R., 1976. Urease activity in the sheep rumen and the isolation of ureolytic bacteria. J. Gen. Microbiol. 92, 32-48

Dawson K.A., Newman K.E., Boling J.A., 1990. Effects of microbial supplements containing ycast and lactobacilli on roughage - fed ruminal microbial activities. J. Anim. Sci. 68, 3392-3398

Farkas V., Liskova M., Biely P., 1985. Novel media for detection of microbial producers of cellulase and xylanase. FEMS Microbiol. Lett. 28, 137-140

Harrison G.A., Hemken R.W., Dawson K.A., Harmon R.J., Barker K.B., 1988. Influence of addition of yeast culture supplement to diets of lactating cows on ruminal fermentation and microbial populations. J. Dairy Sci. 71, 2967-2975

Lund A., 1974. Yeast and moulds in the bovine rumen. J. Gen. Microbiol. 81, 453-459

Newbold C.J., Wallace R.J., 1992. The effect of yeast and distillery by-products on the fermentation in the rumen simulation technique (Rusitec). Anim. Prod., 54, Abstr. 210

Somogyi M., 1952. Notes on sugar determination. J. Biol. Chem. 195, 19-23

Wiedmeier R.D., Arambel M.J., Walters J.L., 1987. Effect of yeast culture and Aspergillus oryzae fermentation cxtract on ruminal characteristics and nutrient digestibility. J. Dairy. Sci. 70, 2063-2071

Wallace R.J., 1992. Manipulation of rumen function: Ionophores, Yeast culture and biotechnology. In: Improving nutrient utilization while reducing pollution. 6th European Lecture Tour. Alltech, Inc. Nicholasville, 113-123

Wojciechowicz. M., 1971. Partial characterization of pectinolytic enzymes of Bacteroides ruminicola isolated from rumen of a sheep. Acta microb. pol., Ser. A, 3, 45-50

\section{STRESZCZENIE}

\section{Wpływ drożdży pektynolitycznych na mikroflorę żwacza}

$\mathrm{W}$ doświadczeniu in vitro $\mathrm{i}$ in vivo badano wpływ kultury drożdży Kluyveromyces marxianus CCY 51-1-1 na wzrost beztlenowców bakterii celulolitycznych, amylolitycznych i pektynolitycznych oraz na aktywność enzymatyczną (celulazy, amylazy, pektynazy i ureazy) mikroflory żwacza. Stwierdzono istotne zwiększenie aktywności celulazy i $x$-amylazy w doświadczeniu in vitro, w którym przez 24 godz. płynną treść żwacza cieląt i owiec inkubowano z dodatkiem drożdży. Zwiększenie aktywności celulazy, $\alpha$-amylazy oraz pektynazy, a obniżenie aktywności ureazy wykazano w 3 tygodnie po dodaniu kultur drożdży do dawki dla owiec. Nie stwierdzono wpływu dodatku drożdży na liczebność baktcrii żwaça, a zawartość drożdży w ciągu 8 godz. podczas inkubacji płynnej treści jiwacza in vitro byla stala. 